\title{
Antioxidative and Antimutagenic Activities of 70\% Ethanolic Extracts from Four Fungal Mycelia-Fermented Specialty Rices
}

\author{
Mi Ra Yoon ${ }^{1}$, Seok Hyun $\mathrm{Nam}^{2, *}$, and Mi Young Kang ${ }^{1}$ \\ ${ }^{1}$ Department of Food Science and Nutrition, Kyungpook National University, \\ 1370 Sankyuk-dong, Puk-gu, Daegu 702-701, Korea \\ ${ }^{2}$ Department of Biological Science, Ajou University, 5 Woncheon-dong, Yeongtong-gu, Suwon 443-749, Korea
}

Received 8 April, 2008; Accepted 22 April, 2008

\begin{abstract}
Summary The health-promoting potential of $70 \%$ ethanolic extracts of 4 rice varieties fermented with Monascus ruber, Phellinus linteus, Cordyceps sinensis and Agaricus blazei was evaluated mainly focusing on their antioxidative and antimutagenic capacities based on the following parameters: phenolic compound and phytic acid content; inhibitory activity on lipid peroxidation; scavenging activity on DPPH radical; suppressing ability on mitomycin C-induced mutagenesis in $E$. coli cells; and protective effect on 4-nitroquinoline oxide-triggered DNA lesion in V79 hamster cells. The fermented rice extracts were superior in overall health-promoting parameters compared to the source material. The higher antimutagenic activity of the fermented rice extracts might be in part caused by a larger amount of antioxidant constituents such as phenolic compounds or phytic acid. Of the fungal species, Monascus ruber was found to impart a marked increase in both the antioxidative and antimutagenic abilities to the source material. The current study suggests a possibility that such fermented rice may contribute to the prevention of lifestyle-related diseases such as cancer through a daily intake of rice-based diets.
\end{abstract}

Key Words: antioxidation, antimutagenesis, anticarcinogenesis, fermented rice, fungal mycelia

\section{Introduction}

The spontaneous generation of reactive oxygen species (ROS) has widely been accepted as an inevitable phenomenon that occurs in the process of the aerobic cell respiration. Despite its advantage in the efficient free energy transition from fuel molecules to ATP, concomitant ROS generation much greater than a physiologically relevant level has been reported as a harmful event causing the oxidative destruction of constituents in the aerobic cells [1]. Emerging evidence indicates that such a cellular dysfunction caused by ROS might play a pivotal role in the pathogenesis of chronic

\footnotetext{
*To whom correspondence should be addressed

Tel: +82-31-219-2619 Fax: +82-31-219-1615

E-mail: shnam@ajou.ac.kr
}

lifestyle-related diseases including atherosclerosis and cancer as well as aging [2-4].

For protecting against oxidative damages, aerobic cells are equipped with a variety of antioxidants with different functions and antioxidative enzymes, by which cellular redox-status homeostasis is ensured through the scavenging of various preformed ROSs [5-7]. Therefore, much attention has been paid to the prevention or amelioration of oxidative stress-related chronic diseases through daily intake of antioxidant-rich functional foods.

Recently, the medicinal use of rice has been regarded as one of the cost-effective ways to ensure quality of life in the aging society through the prevention of lifestyle-related diseases without creating any immense economic burden. A variety of health-promoting specialty rice is now commercially available, the majority of which is polished rice coated with well-known functional materials such as antioxidant 
vitamins or herbal extracts which have already demonstrated their pharmaceutical potency in folk medicine. As well, germinated rice or fermented rice made by cultivating fungal mycelia on the rice grain is commercially available specialty rice [8]. The fungal mycelia growth on rice is implicated as a valuable process to enhance health-promoting ability of rice grain; however, critical evaluation for its medicinal potency has to be done with a range of tests for elucidation of its validity as a marketable healthy food.

In this context, antioxidant and antimutagenic activities, regarded as the primary health-promoting parameters in medicinal potencies, were examined with the specialty rice fermented with each of 4 mycelia of Agaricus blazei, Phellinus linteus, Cordyceps sinensis and Monascus ruber, especially focusing on the phenolic compound and phytic acid contents, inhibitory activity on lipid autoxidation and scavenging ability on free radical, antimutagenic activities in both bacterial cell system and cultured mammalian cell system, respectively. The current study showed that the fermented rice varieties tested had both improved antioxidative and antimutagenic activities, and that Monascus rubber was the most effective in imparting these health-promoting functionalities to the source material.

\section{Materials and Methods}

\section{Materials}

1,1-Diphenyl-2-picrylhydrazyl (DPPH), ferric chloride, 3(4,5-dimethylthiazol-2-yl)-2,5-diphenyl tetrazolium bromide, 2-nitrophenyl- $\beta$-D-galactopyranoside (ONPG), 4-nitrophenyl phosphate (PNPP), mitomycin $\mathrm{C}$, 4-nitroquinoline-1-oxide (4-NQO), and other chemicals were purchased from Sigma Chemical Co. (St. Louis, MO). All reagents were of analytical grade and were used without further purification. E. coli PQ37 strain was kindly provided by Dr. I.M. Chang, Natural Products Research Institute, Seoul National University (Seoul, Korea). V79 strain of Chinese hamster lung cells was purchased from Health Science Research Resources Bank (Osaka, Japan). Eagle's minimum essential media, Hanks' balanced salt solution (HBSS), fetal bovine serum (FBS) and other reagents for mammalian cell culture were the products of Life Technologies (Grand Island, NY).

\section{Rice extracts}

Four commercially available fermented rice varieties, made by cultivating the mycelia of Agaricus blazei, Phellinus linteus, Cordyceps sinensis and Monascus ruber on unpolished rice, together with the source material, were provided by Shinzi Co. (Suwon, Korea). The rice was ground into powder with a blender (Food processor, J World Tech Co., Korea), and passed through a 100-mesh sieve to obtain fine powders. The active compounds in the rice were extracted by shaking overnight at an ambient temperature with 5-times the sample weight of 70\%-30\% ethanol-water [9]. The filtrate was passed through Whatman No. 1 filter paper (Whatman International Ltd., Maidstone, UK). The solvent was then removed from the extract by rotary evaporation (EYELA, Tokyo, Japan) at room temperature. The extracts were dissolved in dimethyl sulfoxid (DMSO) and stored at $-20^{\circ} \mathrm{C}$ until analyzed. For convenience, the extracts from the rice varieties fermented with Agaricus blazei, Phellinus linteus, Cordyceps sinensis and Monascus ruber and the unpolished rice used as source material, are hereafter termed as ABRE, PLRE, CSRE, MRRE and UBRE, respectively.

\section{Analysis of general components}

Moisture, protein, lipid and other macrocomponents were measured following the procedure previously reported [10]. Rice was burned at $550^{\circ} \mathrm{C}$ electric furnace (HMF-3M, Dae Duck Hi-Tech Co., Seoul, Korea) to produce ash for subsequent quantification. Dietary fiber was quantified according to the Prosky-AOAC method based on the enzymatic gravimetric procedure [11]. The crude protein content was measured by the Kjeldahl method using an auto analyzer (1035, Kjeltec Co., Tecator, Sweden). Moisture content was measured using the Infrared moisture determination balance (FD-240, Kett Electronic Lab., Tokyo, Japan).

\section{Quantification of phenolic compound and phytic acid}

The phenolic compound content was determined according to the method of Singleton and Rossi [12] with slight modifications. Briefly, deionized water was added to a rice extract $(0.5 \mathrm{ml})$ to a volume of $7 \mathrm{ml}$, followed by addition of $50 \%$ Folin-ciocalteu's phenol $(0.5 \mathrm{ml})$. After standing for $3 \mathrm{~min}$ at room temperature, $\mathrm{Na}_{2} \mathrm{CO}_{3}$ solution $(1 \mathrm{ml})$ was added to the mixture, and the reaction continued for another $1 \mathrm{~h}$ at room temperature with intermittent mixing. The phenolic compound in the mixture was measured spectrophotometrically at $725 \mathrm{~nm}$ using a UV/Vis spectrophotometer (V-550, JASCO International Co., Tokyo, Japan) to express its quantity as gallic acid equivalents (mg GAE/g sample) with reference to the standard curve using gallic acid as a standard compound.

To measure phytic acid, the method of Fruhbeck and others [13] was applied with a slight modification. Briefly, the rice powder was extracted with $50 \mathrm{ml}$ of $1.2 \% \mathrm{HCl}$ containing $10 \% \mathrm{Na}_{2} \mathrm{SO}_{4}$ by shaking at room temperature. After recovery of the filtrated solution, aliquot $(10 \mathrm{ml})$ was mixed with $12 \mathrm{ml}$ ferric chloride $\left(\mathrm{FeCl}_{3}\right)$, followed by heating in boiling water for $75 \mathrm{~min}$ and subsequent cooling for $1 \mathrm{~h}$. The mixture was then centrifuged at 3,500 rpm for $15 \mathrm{~min}$ to precipitate the resultant ferric phytate. After dissolving the precipitants in $50 \mathrm{ml}$ of distilled water, $4 \mathrm{ml}$ of aliquot from the ferric phytate solution were mixed with $1 \mathrm{ml}$ of Wade reagent. The phytic acid in the solution was 
measured spectrophotometrically at $500 \mathrm{~nm}$, and its quantity was expressed with reference to the standard curve using a sodium phytate reagent.

\section{Inhibition of linoleic acid peroxidation}

The in vitro antioxidant activity of the rice extracts was measured following the thiocyanate method [14]. Briefly, rice extracts $(200 \mu \mathrm{g})$ were mixed with five volumes of $0.02 \mathrm{mM}$ linoleic acid in ethanolic emulsion and 4 volumes of $0.2 \mathrm{M}$ phosphate buffer ( $\mathrm{pH} 7.0)$ in a test tube. The mixture was then placed in the dark for 8 days at $40^{\circ} \mathrm{C}$ to accelerate lipid oxidation. At appropriate intervals, the reaction mixture was withdrawn, and mixed with the ferric chloride and thiocyanate solution. The resultant chromophore production was measured at $500 \mathrm{~nm}$ using a UV/ Vis spectrophotometer, and the absorbance value was used to calculate the magnitude of lipid peroxidation level.

\section{Free radical-scavenging activity on DPPH}

The electron-donating ability of the rice extracts toward the DPPH radical was examined according to the method described by Yen and Chen [15] as follows. The assay mixture consisting of the rice extract and DPPH (final concentration of $100 \mu \mathrm{g} / \mathrm{ml}$ and $0.2 \mathrm{mM}$, respectively) was shaken vigorously for $5 \mathrm{~min}$ and placed for $30 \mathrm{~min}$ at room temperature in the dark, and then the absorbance of the mixture was recorded at $517 \mathrm{~nm}$. Special care was taken to minimize the loss of free radical activity of the DPPH stock solution as recommended in the original article, i.e., preliminarily, the integrity of the DPPH solution is tested using $100 \mathrm{mM}$ sodium acetate buffer ( $\mathrm{pH} \mathrm{5.5)}$ as the replacement for the DPPH solution. The radical scavenging activity of the rice extracts was expressed as the percent inhibition relative to the control.

\section{SOS chromotest}

A SOS chromotest was carried out according to the procedure described by Quillardet and Hofnung [16] in a modified version recommended by Mersch-Sundermann and others [17]. An overnight culture of E. coli PQ37 was 10-fold diluted with $\mathrm{LB}$ medium, and cultured for $2 \mathrm{~h}$ at $37^{\circ} \mathrm{C}$. Then, rice extracts (final concentration $100 \mu \mathrm{g} / \mathrm{ml}$ ) and/or mitomycin $\mathrm{C}$ (final concentration $6 \mathrm{ng} / \mathrm{ml}$ ) were added to the aliquots, previously 4 -fold prediluted with the flesh medium. After incubation for $2 \mathrm{~h}$ at $37^{\circ} \mathrm{C}$, the bacterial cells were used for the following assays: To measure the $\beta$-galactosidase activity, culture aliquots $(0.2 \mathrm{ml})$ were 10 -fold diluted with B buffer $\left(120 \mathrm{mM} \mathrm{Na} \mathrm{HPO}_{4}, 40 \mathrm{mM} \mathrm{NaH} \mathrm{PO}_{4}, 10 \mathrm{mM}\right.$ $\mathrm{KCl}, 1 \mathrm{mM} \mathrm{MgSO}_{4}, 50 \mathrm{mM} \beta$-mercaptoethanol, $1 \% \mathrm{SDS}$, $\mathrm{pH}$ 7.0). The enzyme assay was started by adding $1.6 \mathrm{mg}$ of ONPG, followed by incubation for $20 \mathrm{~min}$ at $37^{\circ} \mathrm{C}$ with continual shaking. Then, $\mathrm{Na}_{2} \mathrm{CO}_{3}$ was added to terminate the reaction, and the enzyme activity was measured spectro- photometrically at $420 \mathrm{~nm}$. For the alkaline phosphatase assay, culture aliquots were 10-fold diluted with $\mathrm{P}$ buffer (1 M Tris, $0.1 \% \mathrm{SDS}$ ), and then incubated for $30 \mathrm{~min}$ at $37^{\circ} \mathrm{C}$ in the presence of $1.6 \mathrm{mg}$ PNPP. After terminating the reaction with $\mathrm{HCl}$, the enzyme activity was also measured spectrophotometrically at $420 \mathrm{~nm}$. The enzyme activities were calculated according to the following formula:

Enzyme units

$=$ absorbance at $420 \mathrm{~nm} \times 1000 / t[t=$ substrate conversion time (min)].

The induction factor $(R)$ was expressed as a ratio of $\beta$ galactosidase unit to alkaline phosphatase unit. Antimutagenicity was defined as follows:

Antimutagenicity (\%)

$=\left[1-\left(R_{x}-R_{0}\right) /\left(R_{c}-R_{0}\right)\right] \times 100\left(R_{x}, R_{c}\right.$, and $R_{0}$; Induction factor of experimental group, only mitomycin C-treated positive control and blank, respectively)

\section{Cytotoxicity assay in Chinese hamster V79 cells}

The V79 strain of Chinese hamster lung cells was maintained in Eagle's minimum essential medium (MEM) supplemented with $10 \%$ heat-inactivated fetal bovine serum (FBS) with 100 units $/ \mathrm{ml}$ penicillin and $100 \mu \mathrm{g} / \mathrm{ml}$ streptomycin under $5 \% \mathrm{CO}_{2}$-contained humidified air. The cytotoxicity on the V79 cells was determined by measuring the colony-forming activity (CFA) of cells pretreated with the rice extracts. Briefly, triplicate inocula of $5 \times 10^{2}$ cells were incubated in 100-mm cell dishes in the medium for $24 \mathrm{~h}$, followed by treatments with various doses of rice extracts for $3 \mathrm{~h}$. After rinsing with HBSS, the media were added, and incubation continued for 7 days. The cell colonies formed on the culture dishes were fixed with methanol and stained with Giemsa solution (Sigma Chemical Co.). Colonies containing more than 50 cells were scored under a microscope, and the CFA was calculated from the average number of colonies as a percentage of the number of cells initially inoculated. The effect of the rice extracts on cell survival is expressed as the surviving fractions of the CFA with reference to that of the untreated control cultures.

The antimutagenic ability of the rice extracts was determined following the re-plating method previously reported [2]. The inocula of $2 \times 10^{5}$ cells in $100-\mathrm{mm}$ dishes were incubated for $24 \mathrm{~h}$ and then treated with the mutagen, 4nitroquinoline oxide (4-NQO), at a concentration of $1.5 \times$ $10^{-7} \mathrm{M}$ for $3 \mathrm{~h}$. After rinsing twice with HBSS to remove the mutagen completely, the cells were incubated for 7 days in the medium to allow for maximal expression of mutagenicity. Then, the cells were dissociated by treatment with $0.25 \%$ trypsin containing $0.02 \%$ EDTA, followed by replating $2 \times 10^{5}$ cells in five $100-\mathrm{mm}$ dishes in the medium containing $5 \mu \mathrm{g} / \mathrm{ml}$ of 6 -thiaguanine (6TG) for 8 days. The resultant 6TG-resistant mutant colonies were fixed, stained, and scored for the number of colony-forming units. In 
parallel experiments, triplicate inocular of $5 \times 10^{2}$ cells, each in $100-\mathrm{mm}$ dishes, were incubated in the medium without 6TG for 7 days. The CFA of the replated cells was determined as described above. The number of induced mutants was calculated by subtracting the number of colonies in the untreated control cultures from those in the treated cultures. The induced mutation frequency (IMF) was expressed as the number of induced mutants per $10^{5}$ colony-forming cells.

\section{Statistical analysis}

All statistical analyses were conducted using the statistical package for social science software program (SPSS ver. 11, SPSS Inc., Chicago, IL). Data were presented as the mean \pm SD. Significant differences among the groups were determined by a one-way analysis of variance (ANOVA) with a post hoc Duncan's multiple-range test. Probability values $<0.05$ were considered to be statistically significant.

\section{Results}

\section{General chemical composition}

The protein, lipid, ash, dietary fiber and moisture contents of 4 fermented rice extracts were significantly altered compared to those of the source material (Table 1); cultivation of the fungal mycelia increased the crude protein and dietary fiber contents, while vice versa for the ash and moisture contents. The fermented rice extracts, except for MRRE, tended to show a lower lipid content. MRRE exhibited the greatest increase in the protein and dietary fiber contents, and CSRE the greatest decrease in the lipid and ash contents.

\section{Phenolic compounds and phytic acid contents}

The phenolic compound and phytic acid contents were quantified as an index to evaluate the health-promoting potentials of the fermented rice varieties. The 4 fungal mycelia growths on the rice significantly gave rise to the overall increase in the phenolic compounds content compared to that of the source material. Among them, the highest increase in the phenolic compounds content (about

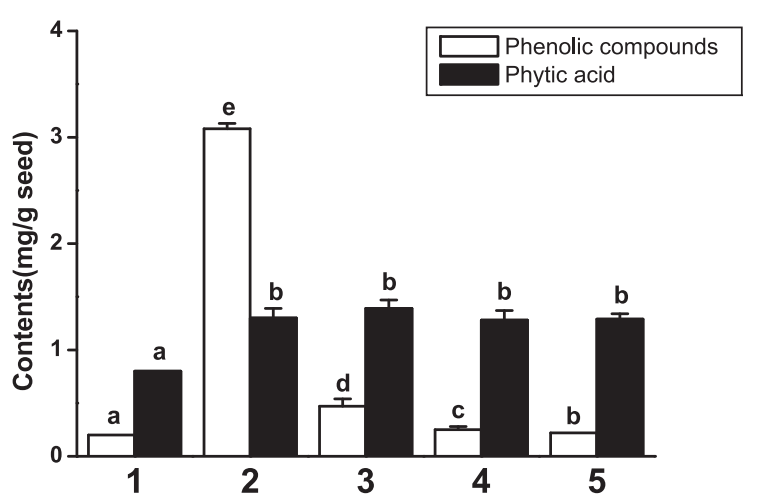

Fig. 1. Phenolic compounds and phytic acid contents in $70 \%$ ethanol extract of the following rices. Lane 1, unpolished brown rice used as the source material; lane 2, Monascus rubber-fermented rice; lane 3, Phellinus linteusfermented rice; lane 4, Cordyceps sinensis-fermented rice; lane 5, Agaricus blazeis-fermented rice. Values are expressed as mean $\pm \mathrm{SD}$. The means not sharing a common letter are significantly different between groups at $p<0.05(n=3)$.

16-fold) was observed with MRRE compared with the source material, and the phenolic compound content of each fermented rice extract decreased in the order of PLRE > CSRE $>$ ABRE (Fig. 1). The fungal mycelia growth also indicated overall increase in the phytic acid content compared to the source material, however, no significant quantitative differences could be found among the 4 fermented rice extracts.

\section{Antioxidative activity}

The antioxidant activity of the fermented rice extracts was determined as a valuable parameter to simply evaluate their health-promoting capacities. Therefore, the inhibitory activity of the fermented rice extracts on lipid autoxidation was first measured in the assay system using linoleic acid as a substrate for oxidation reaction. The results show that the inhibitory activity was higher in the fermented rice extracts than the source material extract (Table 2), and that the inhibitory

Table 1. General chemical composition of the fermented rices ${ }^{\dagger}$

\begin{tabular}{cccccc}
\multicolumn{1}{l}{ \%) } \\
\hline Rice & Protein & Lipid & Ash & Dietary fiber & Moisture \\
\hline UBR & $5.87 \pm 0.26^{\mathrm{a}}$ & $2.0 \pm 0.08^{\mathrm{c}}$ & $0.3 \pm 0.03^{\mathrm{e}}$ & $0.78 \pm 0.01^{\mathrm{a}}$ & $12.32 \pm 0.36^{\mathrm{d}}$ \\
MRR & $8.29 \pm 0.1^{\mathrm{d}}$ & $3.48 \pm 0.21^{\mathrm{d}}$ & $0.16 \pm 0.01^{\mathrm{b}}$ & $4.84 \pm 0.08^{\mathrm{d}}$ & $11.3 \pm 0.26^{\mathrm{d}}$ \\
PLR & $7.19 \pm 0.11^{\mathrm{bc}}$ & $1.29 \pm 0.03^{\mathrm{b}}$ & $0.22 \pm 0.01^{\mathrm{c}}$ & $3.98 \pm 0.88^{\mathrm{c}}$ & $6.31 \pm 0.16^{\mathrm{cd}}$ \\
CSR & $6.99 \pm 0.14^{\mathrm{b}}$ & $0.55 \pm 0.03^{\mathrm{a}}$ & $0.12 \pm 0.01^{\mathrm{a}}$ & $3.25 \pm 0.29^{\mathrm{bc}}$ & $7.51 \pm 0.08^{\mathrm{bc}}$ \\
ABR & $7.32 \pm 0.1^{\mathrm{c}}$ & $1.5 \pm 0.08^{\mathrm{b}}$ & $0.25 \pm 0.02^{\mathrm{d}}$ & $2.87 \pm 0.05^{\mathrm{b}}$ & $6.68 \pm 0.34^{\mathrm{a}}$ \\
\hline
\end{tabular}

Values in each column with the same superscript are not significantly different at $p<0.05$. Values are expressed as mean \pm SD $(n=3)$. $\$$ The rice fermented with the mycelia of Monascus ruber, Phellinus linteus, Cordyceps sinensis and Agaricus blazei are termed as MRR, PLR, CSR and ABR, respectively. UBR means unpolished brown rice used as the source material. 
Table 2. Antioxidative activities of the fermented rice extracts ${ }^{\dagger}$

\begin{tabular}{|c|c|c|c|c|}
\hline \multirow{2}{*}{ Rice extract } & \multicolumn{2}{|c|}{ Inhibition of linoleic acid peroxidation } & \multicolumn{2}{|c|}{ Scavenging of DPPH radical } \\
\hline & Absorbance at $500 \mathrm{~nm}$ & Inhibition (\%) & Absorbance at $517 \mathrm{~nm}$ & Inhibition (\%) \\
\hline Control & $1.059 \pm 0.054$ & 0 & $3.098 \pm 0.254$ & 0 \\
\hline BHT & $0.097 \pm 0.004^{\mathrm{a}}$ & 90.8 & $0.325 \pm 0.027^{\mathrm{a}}$ & 89.5 \\
\hline UBRE & $0.509 \pm 0.051^{\mathrm{e}}$ & 51.9 & $2.447 \pm 0.151^{\mathrm{f}}$ & 21 \\
\hline MRRE & $0.163 \pm 0.024^{b}$ & 84.6 & $0.504 \pm 0.034^{\mathrm{b}}$ & 84.6 \\
\hline PLRE & $0.223 \pm 0.032^{\mathrm{c}}$ & 78.9 & $1.115 \pm 0.092^{\mathrm{c}}$ & 64 \\
\hline CSRE & $0.431 \pm 0.022^{\mathrm{d}}$ & 59.3 & $1.379 \pm 0.102^{\mathrm{d}}$ & 45.2 \\
\hline ABRE & $0.485 \pm 0.024^{\mathrm{e}}$ & 54.2 & $1.902 \pm 0.112^{\mathrm{e}}$ & 38.6 \\
\hline
\end{tabular}

Values in each column with the same superscript are not significantly different at $p<0.05$. Values are expressed as mean $\pm \mathrm{SD}(n=3)$. ${ }^{\star}$ The extracts from rice fermented with the mycelia of Monascus ruber, Phellinus linteus, Cordyceps sinensis and Agaricus blazei are termed as MRRE, PLRE, CSRE and ABRE, respectively. UBRE, used as an internal control, means the extract from unpolished brown rice, source material. See sample concentration in Materials and Methods. BHT was used at a dose of $200 \mu \mathrm{g}$.

Table 3. Inhibitory effects of the fermented rice extracts on mitomycin C-induced mutagenesis in E. coli PQ37 cells

\begin{tabular}{ccccc}
\hline Rice extract $^{\dagger}$ & $\begin{array}{c}\beta \text {-galactosidase } \\
\text { activity (unit) }\end{array}$ & $\begin{array}{c}\text { Alkaline phosphatase } \\
\text { activity (unit) }\end{array}$ & R factor & $\begin{array}{c}\text { Antimutagenicity } \\
(\%)\end{array}$ \\
\hline Control (-) & $6.71 \pm 0.57$ & $40.37 \pm 0.97$ & 0.17 & 100 \\
Control (+) & $19.19 \pm 0.24$ & $14.69 \pm 1.07$ & 1.31 & 0 \\
\hline UBRE $^{1)}$ & $18.18 \pm 1.43$ & $15.77 \pm 1.10$ & 1.15 & 14 \\
MRRE & $16.34 \pm 1.99$ & $19.62 \pm 1.27$ & 0.83 & 42.1 \\
PLRE & $14.17 \pm 0.39$ & $16.88 \pm 1.02$ & 0.84 & 41.2 \\
CSRE & $9.55 \pm 0.39$ & $14.16 \pm 1.15$ & 0.67 & 56.1 \\
ABRE & $15.35 \pm 0.93$ & $15.97 \pm 0.91$ & 0.96 & 30.7 \\
\hline
\end{tabular}

${ }^{\dagger}$ See footnote to Table 2. *Values represent percent inhibition of cells loaded simultaneously with mitomycin $\mathrm{C}$ and rice extracts compared to maximum values from cells stimulated with only mitomycin $\mathrm{C}$ treatment (positive control).

action of MRRE, PLRE, CSRE and ABRE decreased in that order. Second, the free radical scavenging ability was also measured as another parameter of the antioxidativity. The results show that the radical scavenging ability of the fermented rice extracts was higher than that of the source material, and that the activity decreased in the order of MRRE $>$ PLRE $>$ CSRE $>$ ABRE

\section{Antimutagenic activity in SOS chromotest system}

The inhibitory effect of the fermented rice extracts on chemically induced mutagenesis was assessed in the SOS chromotest using E. coli as an indicator cell. Data in Table 3 shows that CSRE have suppressed mitomycin C-induced mutagenesis more potently than other fermented rice extracts such as MRRE and PLRE (about 56\% vs. 41 42\% inhibitions). On the other hand, ABRE exhibited the lowest antimutagenic activity (about 30\% inhibition).
Cytotoxicity of the rice extracts in mammalian cell system

To assess the antimutagenicity of the fermented rice extracts accurately, the rice extract doses without any marked cytotoxicity and mutagenicity were first measured in V79 Chinese hamster cells. The results show that the optimal dose of rice extracts varied with each of the rice extracts; at 120, 20, 160 and $80 \mu \mathrm{g} / \mathrm{ml}$ or a higher dose of UBRE, MRRE, PLRE and CSRE, respectively, cell viabilities were markedly diminished to a level less than 0.94 of the surviving fraction of cells (Table 4). Therefore, $80,10,120,40$ and $5 \mu \mathrm{g} / \mathrm{ml}$ of UBRE, MRRE, PLRE, CSRE and ABRE were determined to be the satisfactory doses for conducting further assessments of the antimutagenicity of the rice extracts.

\section{Antimutagenic activity of the rice extracts in mammalian cell system}

A preliminary test has demonstrated that a value of induced mutation frequency by mutagen 4-NQO reached its 
Table 4. Cytotoxicity and mutagenicity test of the fermented rice extracts in V79 cells

\begin{tabular}{cccccc}
\hline $\begin{array}{c}\text { Concentration } \\
(\mu \mathrm{g} / \mathrm{mL})\end{array}$ & \multicolumn{5}{c}{${\text { Surviving fraction of cells }{ }^{\dagger}}$} \\
\cline { 2 - 6 } & UBRE $^{\ddagger}$ & MRRE & PLRE & CSRE & ABRE \\
\hline 0 & 1 & 1 & 1 & 1 & 1.133 \\
5 & 1.109 & 0.934 & 1.276 & 1.191 & 0.923 \\
10 & 1.048 & 0.948 & 1.146 & 1.133 & 0.812 \\
20 & 1.018 & 0.913 & 1.233 & 1.122 & 0.895 \\
40 & 1 & 0.918 & 1.22 & 0.82 & 0.789 \\
80 & 0.971 & 0.747 & 1.187 & 0.028 & 0.516 \\
120 & 0.912 & 0.329 & 1.152 & ND & 0.394 \\
160 & 0.695 & ND & 0.896 & ND \\
\hline
\end{tabular}

${ }^{\dagger}$ Induced mutation frequency per $10^{5}$ surviving cells was 0.000 . ${ }^{*}$ See footnote to Table 2 . ND; not determined.

maximum at a dose of $1.5 \times 10^{-7} \mathrm{M}$ in V79 cells (data not shown). Therefore, under these mutagen and rice extract concentrations, the protective effect of rice extracts on 4NQO-induced mutagenesis was measured to see if the antimutagenic potency was enhanced in the fermented rice extracts compared to the source material. Data show that MRRE, PLRE and ABRE exhibited over 5-fold greater antimutagenic potencies relative to the source material, and that the activity decreased in the order of MRRE $>$ ABRE $>$ PLRE $>$ CSRE $>$ UBRE if was taken no account of the difference in sample doses.

\section{Discussion}

A growing number of chemical carcinogens are now encountered in the environment at suspected doses to induce mutagenesis or carcinogenesis. To count the impact of cancer in an aging society, dietary control seems likely to be the most desirable preventive way which is not accompanied by any immense social economic burden on public health care. In this consequence, the current study is undertaken to examine whether 4 commercially available rice varieties made by cultivating fungal mycelia on unpolished rice grains have health-promoting potencies worthy for daily intake. Experiments were mainly conducted to evaluate the antioxidant and antimutagenic effects of fermented rice varieties. First, this study noted the alteration in both phenolic compound and phytic acid contents, well-known health-promoting phytochemicals $[18,19]$. The data show a significant increase in both phenolic compound and phytic acid contents in the fermented rice varieties compared to the source material itself (Fig. 1). Especially, a remarkable increase in the phenolic compound content was observed with MRRE. These findings might be a clue that the enhanced antioxidant capacities of the 4 fermented rice extracts are associated with the increase in the phenolic compound and phytic acid contents (Table 2). This notion is supported by a number of studies on the action of phenolic compound and phytic acid in suppressing ROS-triggered oxidative DNA damage $[18,20]$. As it is considered that irreversible mutations in DNA trigger tumorigenesis through so-called 'tumor-initiation' step [21], it is crucial to examine whether the enhanced antioxidant activity observed with the fermented rice extracts is coupled with the raised antimutagenic activity in cell milieu. Data in Table 3 show that the extent of inhibitory actions of the rice extracts, except for CSRE, on mitomycin C-induced mutagenesis tends to be parallel with their antioxidant potentials in E. coli PQ37 cells. This might indicate a pivotal role of phenolic compound in the expression of antimutagenic potential [22]. MRRE would be the representative example, and a number of earlier studies indicate that phenolic antioxidants inhibit a substantial variety of chemical carcinogens including mitomycin $\mathrm{C}$ by their radical scavenging action toward highly reactive electrophiles of reactive forms of carcinogens. This again supports a possibility that the mutation-suppressing action of the rice extracts observed in the current study is closely coupled with the antioxidant potential [22-24]. However, the current study failed to find such a relationship for CSRE. Alternatively, the non-phenolic components of the fungal mycelia might be involved in the suppression of chemically induced mutagenesis in desmutagenic and/or bio-antimutagenic manners [25], and in that case, the most probable candidate would be the antioxidant polysaccharides known as antitumorigenic components in earlier studies [26-28]. Although a SOS chromotest is a convenient tool to examine the alteration in DNA, the lack of a mixed function oxidase system in bacterial cells hampers an accurate evaluation of the xenotoxicity prerequisite for cellular metabolic conversions [29,30]. In this consequence, V79 Chinese hamster lung fibroblast cells were employed to evaluate the protective effect of the rice extracts on a direct mutagen 4-NQO-induced mutagenesis; the antimutagenic potential of the rice extracts was assessed by measuring the reduction rate of 6-thioguanine resistant cell colony formation resulting from 4-NQO-induced genetic alteration at the 
Table 5. Effects of the fermented rice extracts on 4-NQO-triggered IMF in V79 cells

\begin{tabular}{ccccc}
\hline Rice extract & $\begin{array}{c}\text { Concentration } \\
(\mu \mathrm{g} / \mathrm{mL})\end{array}$ & $\begin{array}{c}\text { 6-TG resistant } \\
\text { Colony number }\end{array}$ & $\begin{array}{c}\text { Induced Mutation } \\
\text { Frequency (IMF) }\end{array}$ & $\begin{array}{c}\text { Inhibition } \\
(\%)\end{array}$ \\
\hline Control $^{\ddagger}$ & - & $13.40 \pm 2.07$ & 34.86 & 0 \\
UBRE & 80 & $14.78 \pm 1.64$ & 29.86 & 14.3 \\
MRRE & 10 & $4.22 \pm 2.17$ & 7.7 & 77.9 \\
PLRE & 120 & $6.33 \pm 1.79$ & 9.76 & 72 \\
CSRE & 40 & $9.14 \pm 2.61$ & 15.4 & 55.8 \\
ABRE & 5 & $5.63 \pm 1.52$ & 8.5 & 75.6 \\
\hline
\end{tabular}

TSee footnote to Table 2. Cells were treated only with $1.5 \times 10^{-7} \mathrm{M} 4$-NQO.

hypoxanthine-guanine phosphoribosyltransferase gene locus [31]. The prominent antimutagenic action of MRRE could also be explained based on a much larger amount of phenolic compounds, as discussed in the results from the SOS chromotest (Table 3), whereas those of other fermented rice extracts did not agree directly with their phenolic compound contents (Table 3). Such a tendency was evident especially in the case of CSRE and ABRE. Moreover, the mutationsuppressing profile seemed inversely related in between the assay systems. In the current study, the antimutagenic effect of the rice extracts on the V79 cells was assessed under the condition that the cells were treated with the extracts during the mutation expression time after treatment with 4-NQO, not simultaneously with the extracts and the mutagen as for the SOS chromotest (see Materials and Methods). Consequently, the mutation-suppressing effects of the rice extracts on the V79 cells might be bio-antimutagenic (Table 5). On the contrary, the SOS chromotest might, in part, exhibit a desmutagenic ability of the rice extracts [32], possibly explaining the discrepancy in antimutagenicity according to the assay system employed.

In conclusion, the current study demonstrates that 4 fungal mycelia-fermented rice extracts have greater mutation-suppressing effects on both chemically induced mutagenesis in the SOS chromotest and the 6-TG resistant colony forming assay using V79 Chinese hamster cells. In addition, their antioxidative potentials might, in large part, play a role in the expression of their antimutagenic activities. Considering that accumulation of irreversible mutations is a primary cause leading to the transformation of normal cell to a cancerous cell, daily intake of the fermented rice is desirable for the prevention of cancer, a most threatening lifestyle-related chronic disease. Therefore, more intensive studies are needed to clarify the mechanism for the mutation-suppressing action of the fermented rice varieties for a wider use of fermented rice as a food with health implications.

\section{Acknowledgments}

This work was supported by a grant (No. 201030-0300063) sponsored by the Korean Agriculture R\&D Promotion Center. The authors thank Dr. Jung-Hyeon Chin, Shinzi Co. (Suwon, Korea) for providing the fermented specialty rice.

\section{References}

[1] Ames, B.N., Shigenaga, M.K., and Hagen, T.M.: Oxidants, antioxidants, and the degenerative diseases of aging. Proc. Natl. Acad. Sci. U.S.A., 90, 7915-7922, 1993.

[2] Nam, S.H., Choi, S.P., Kang, M.Y., Kozukue, N., and Friedman, M.: Antioxidative, antimutagenic, and anticarcinogenic activities of rice bran extracts in chemical and cell assays. J. Agric. Food Chem., 53, 816-822, 2005.

[3] Guo, Z., Ou, W., Lu, S., and Zhong, Q.: Differential responses of antioxidative system to chilling and drought in four rice cultivars differing in sensitivity. Plant Physiol. Biochem., 44, 828-836, 2006.

[4] Chiang, A.N., Wu, H.L., Yeh, H.I., Chu, C.S., Lin, H.C., and Lee, W.C.: Antioxidant effects of black rice extract through the induction of superoxide dismutase and catalase activities. Lipids, 41, 797-803, 2006.

[5] Noguchi, N. and Niki, E.: Dynamics of vitamin E action against LDL oxidation. Free Radic. Res., 28, 561-572, 1998.

[6] Zhang, P. and Omaye, S.T.: DNA strand breakage and oxygen tension: effects of $\beta$-carotene, $\alpha$-tocopherol and ascorbic acid. Food Chem. Toxicol., 39, 239-246, 2001.

[7] DeLong, M.J.: Apoptosis: a modulator of cellular homeostasis and disease states. Ann. N.Y. Acad. Sci., 842, 82-90, 1998.

[8] Kang, M.Y. and Nam, S.H.: Antimutagenic activities of the germinated specialty rices in E. coli and V 79 cultured cell assay systems. J. Korean Soc. Appl. Biol. Chem., 48, 222227, 2005.

[9] Choi, S.W., Nam, S.H., and Choi, H.C.: Antioxidative activity of ethanolic extracts of rice brans. Foods Biotechnol., 5, 305309, 1996.

[10] Padmore, J.M.: AOAC Official Method of Analysis. 15th ed., vol. 1. Washington, Association of Official Analysis Chemists, Washington, pp. 69-90, 1990. 
[11] Prosky, L., Asp, N.G., Schweizer, T.F., Devries, J.W., and Furda, L.: Determination of insoluble, soluble and total dietary fiber in foods and food products: interbaboratory study. J. Assoc. Off. Anal. Chem., 71, 1017-1023, 1988.

[12] Singleton, V.L. and Rossi, J.A.: Colorimetry of total phenolics with phosphomolybdic-phosphotungstic acid reagents. Am. J. Enol. Viticul., 16, 144-153, 1965.

[13] Fruhbeck, G., Alonso, R., Marzo, F., and Santidrian, S.: A modified method for the indirect quantitative analysis of phytate in foodstuffs. Anal. Biochem., 225, 206-212, 1995.

[14] Mitsuda, H., Yasumoto, K., and Iwaki, K.: Antioxidative action of indole compounds during the antoxidation of linoleic acid. Eiyo to Shokuryo, 19, 210-214, 1996.

[15] Yen, G.C. and Chen, H.Y.: Antioxidant activity of various tea extracts in relation to their antimutagenicity. J. Agric. Food Chem., 43, 27-32, 1995.

[16] Quillardet, P. and Hofnung, M.: The SOS chromotest, a colorimetric bacterial assay for genotoxins: procedures. Mutation Res., 147, 65-78, 1985.

[17] Mersch-Sundermann, V., Kevekordes, S., and Mochayedi, S.: Source of variability of the Escherichia coli PQ37 genotoxicity assay (SOS chromotest). Mutation Res., 252, 51-60, 1990.

[18] Nakayama, T.: Suppression of hydroperoxide-induced cytotoxicity by polyphenols. Cancer Res., 54, 1991-1993, 1994.

[19] Shamsuddin, A.M.: Inositol phosphates have novel anticancer function. J. Nutr., 125, 725-732, 1995.

[20] Midorikawa, K., Murata, M., Oikawa, S., Hiraku, Y., and Kawanishi, S.: Protective effect of phytic acid on oxidative DNA damage with reference to cancer chemoprevention. Biochem. Biophys. Res. Commun., 288, 552-557, 2001.

[21] Wattenberg, L.W.: Chemoprevention of cancer. Cancer Res., 45, 1-8, 1985.

[22] Nagasawa, H. and Little, J.B.: Suppression of cytotoxic effect of mitomycin-C by superoxide dismutase in Fanconi's anemia and dyskeratosis congenita fibroblasts. Carcinogenesis, 4,
795-799, 1983.

[23] Speier, J. and Wattenberg, L.W.: Alteration in microsomal metabolism of benzo(a)pyrene in mice fed butylated hydroxyanisole. J. Natl. Cancer Inst., 55, 469-472, 1975.

[24] Miller, J.A.: Brief history of chemical carcinogenesis. Cancer Lett., 83, 9-14, 1994.

[25] Kada, T. and Shimoi, K.: Desmutagens and bio-antimutagens: their mode of action. Bioassays, 7, 113-116, 1987.

[26] Li, S.P., Zhao, K.J., Ji, Z.N., Song, Z.H., Lo, C.K., Cheung, J.K.H., Zhu, S.Q., and Tsim, K.W.K.: A polysaccharide isolated from Cordyceps sinensis, a traditional Chinese medicine, protects $\mathrm{P} 12$ cells against hydrogen peroxideinduced injury. Life Sci., 73, 2503-2513, 2003.

[27] Kim, G.Y., Choi, G.S., Lee, S.H., and Park, Y.M.: Acidic polysaccharide isolated from Phellinus linteus enhances through the up-regulation of nitric oxide and tumor necrosis factor- from peritoneal macrophages. J. Ethnopharmacol., 95, 69-76, 2004.

[28] Ker, Y.B., Chen, K.C., Chyau, C.C., Chen, C.C., Guo, J.H., Hsieh, C.L., Wang, H.E., Peng, C.C., Chang, C.H., and Peng, R.Y.: Antioxidant capability of polysaccharides fractionated from submerge-cultured Agaricus blazei mycelia. J. Agric. Food Chem., 53, 7052-7058, 2005.

[29] Miller, J.A. and Miller, E.C.: The metabolic activation of carcinogenic aromatic amines and amides. Prog. Exp. Tumor Res., 11, 273-301, 1969.

[30] Miller, E.C.: Some current prospectives on chemical carcinogens in human and experimental animals. Cancer Res., 38, 1479-1496, 1978.

[31] Kuroda, Y.: Bio-antimutagenic activity of green tea catechins in cultured Chinese hamster V79 cells. Mutation Res., 361, 179-186, 1996.

[32] Morita, K., Hata, M., and Kada, T.: Studies on natural desmutagens: screening for vegetable and fruit factors active in inactivation of mutagenic pyrolysis products from amino acids. Agric. Biol. Chem., 42, 1235-1238, 1978. 